Volume 3 - Nomor $3 \cdot$ Juni 2020

Pege (Hal.) : $87-93$

(C) Universitas Pamulang

JL.Surya Kencana No.1 Pamulang, Tangerang Selatan - Banten

Telp. (021) 7412566, Fax (021) 7412491

website. :

Email : jurnalmarketing.unpam@gmail.com

\title{
The Correlation of Price and Service Quality on Go-Jek Consumers Satisfaction In Pamulang Tangerang Selatan
}

\author{
Erlita Kurniawaty ${ }^{1}$, Subarto ${ }^{2,}$ Nur Subekhan ${ }^{3}$ \\ ${ }^{123}$ University of Pamulang \\ 1dosen00896@unpam.ac.id, ${ }^{2}$ dosen00363@unpam.ac.id
}

\begin{abstract}
This research aims to determine value of serivce quality and price that affect customer satisfaction of go-jek services in Pamulang area of South Tangerang city from individual and general perspective. The method used is descriptive quantitative with a sample of 100 people. Based on the test results of hypothesis, for the variable of service quality (X1) with $t$ arithmetic $(3,555)>t$ table $(1,988)$, it is obtained that the results are significant itself, that is service quality has an influence on consumer satisfaction of go-jek services in Pamulang, South Tangerang. Similarly, for the variable price (X2) with t arithmetic (3.182) > t table (1.988) obtained significant results on their own, namely the price has an influence on consumer satisfaction of go-jek services in Pamulang, South Tangerang. The calculated $F$ value $(20,802)>F$ table (3.09) with a significance level of $0,000<0.05$, this shows both variables quality of service and price have an influence on customer satisfaction in Pamulang area, South Tangerang.
\end{abstract}

Keywords: Customer Satisfaction; Price; Service Quality

\section{A. INTRODUCTION}

There are still many complaints from the customers in Go-jek services provided by both Go-jek drivers and PT. Go-jek Indonesia as a service provider, at the moment. The Complaints for Go-jek driver services, for example, there are still many Go-jek drivers who do not meet the service standards set by the company, for example, late to pick up the customer, disobeying traffic rules and much more. Meanwhile, complaints against PT. Gojek Indonesia, among others, Go-jek ordering applications often experiencing interference, especially during peak hours and rains. Other than service, customers also complained about the tariff policy set by PT. Go-jek Indonesia, which often changes and feels less competitive. The tariffs that are felt to be less competitive are, for example, minimum rates for Go-ride bookings, price hikes during rush hour for all Go-jek services, and Go-send rates that are felt to be more expensive than similar service rates from competing companies. In addition, for orders Go-send consumer complaints, among others, the goods delivered are damaged and the goods do not reach the consumer.

With a variety of complaints as the authors describe, indicating the quality of service obtained from Gojek's partners is considered not yet optimal due to ignoring the service standards from PT.Go-jek itself. And most likely customers are looking for alternative services from competing companies. In addition, the policy of PT. Go-jek regarding setting tariffs that often changes makes consumer complaints increase. Besides that, the server at PT. Go-jek Jurnal Pemasaran Kompetitif, Vol. 3, No. 3 Juni 2020 
is not perfect yet and sometimes it has a trouble for making orders that may causing complaints from the customers.

The problem formulation as below:

1. Does the quality of Go-jek services affect consumer satisfaction in the Pamulang area of South Tangerang?

2. Does the price of go-jek services affect the consumer satisfaction in the Pamulang area of South Tangerang?

3. Does the quality of service and price simultaneously affect the consumer satisfaction of go-jek services in the Pamulang area of SouthTangerang?

\section{Research Purposes}

1. How much is the influence of service quality on consumer satisfaction for go-jek services in the Pamulang area of SouthTangerang?.

2. How much is the influence of price on customer satisfaction for go-jek services in the Pamulang area of South Tangerang?.

3. How much is the influence of both quality service and price on customer satisfaction of go-jek services in the Pamulang area of South Tangerang?.

\section{B. LITERATURE REVIEW}

According to (Hasibuan, Management: Basics, Understanding and Problems, 2008: 5) says that management is the knowledge or collection of systematic knowledge, which has been collected and generally accepted with an object or certain object and art or a creative, strong personality, and accompanied by skills to regulate, utilize human resources and other resources so that they can be valuable and efficient in order to achieve a certain goal. According to (Griffin, Business, 8th Edition, 2009: 45) said that management is typhical of processing a plan, organization, coordination, and control against the resources to achieving goals effectively and efficiently.

The definition of marketing cited from (Keller PK, 2011:5) is "An organizational function and a set of processes for creating, communicating, and delivering value to consumers and managing customer relationships in ways that benefit the organization and its shareholders." While Marketing science which is a social individuals and groups process get what their need, what they want for exchanging products likes creating, offering with others value (Kotler, Marketing Management, 2009: 134). According to (Keller P. K., Marketing Management, 2009: 5) "Marketing is a social process in which group individuals get what they want by creating, offering and freely exchanging valuable products and services with others."

Service quality is unstable condition that influences the processes in which includes products, services, people and environments that achieve or exceed the expectations (Chandra, 2011: 51). In this case the understanding of service quality is the fulfillment of customer needs and desires and the success of communication in order to realizing customer expectations. Service quality is a crucial thing that needs to be actualized by the company, because it has a great impact to attract new customers and reduce the possibilities of old customers to walk away from the companies. "Service quality is also can be intrepreted as 
the expected level of excellence, and it was meant to reach the customer needs (Tjiptono, Management Services, 2008: 85)

According to (Keller P. K., Marketing Management, 2011: 67) the definition of price is the marketing mix whose elements generate income, other elements produce costs. According to (Tjiptono, Marketing Services, 2011: 151) explains that the profits of company comes from nothing but price itself. Referring to (Armstrong, 2011: 345) price is a payment for buying products or using services which is customers can get the benefit and value from them.

Consumer satisfaction is a feeling that comes right after comparing performances, obtained results, and expectations (Kotler, Marketing Management, 2010: 36). Furthermore according to (Keller P. K., 2011) customer satisfaction is a feel of excitement or disappointment which appears after seeing and comparing some product performances with the expected ones. Thus consumer satisfaction can be interpreted that customer satisfaction is the difference between customer's wish, with the situation given by the company in an effort to reach the customer expectations.

\section{RESEARCH METHOD}

This research use a descriptive quantitative method with a population of 129 respondents who use go-jek services in Pamulang District, South Tangerang City. Samples were taken from the population with Slovin formulas and obtained as many as 100 respondents. And data analysis using several tests including instrument testing (data validity test and data reliability test), correlation test, regression test and hypothesis test.

\section{RESULT AND DISCUSSION}

Based on the instrument test, we can draw the conclusions that all statements for the instrument test are valid and reliable. "T test" is to determine the significance of influence between independent variables partially to the dependent variables.

Table 1 Hypothesis of Testing coefficients $^{\mathrm{a}}$

\begin{tabular}{|c|c|c|c|c|c|}
\hline \multirow[t]{2}{*}{ model } & \multicolumn{2}{|c|}{$\begin{array}{l}\text { unstandardized } \\
\text { coefficients }\end{array}$} & $\begin{array}{l}\text { standardized } \\
\text { coefficients }\end{array}$ & \multirow[t]{2}{*}{$\mathrm{T}$} & \multirow[t]{2}{*}{ Significancy } \\
\hline & $B$ & $\begin{array}{l}\text { Standard } \\
\text { Error }\end{array}$ & Beta & & \\
\hline & 6.332 & 1.658 & & 3.820 & .000 \\
\hline Service $X_{1}$ & .160 & .045 & .339 & 3.555 & .001 \\
\hline Price $X_{2}$ & .280 & .088 & .303 & 3.182 & .002 \\
\hline
\end{tabular}




\section{a. Dependent of Variable: Y satisfaction \\ Source : Processed Primary Data}

Based on the above data, the significance value of the service quality variable (X1) is $0.01<0.05$, and $t$ arithmetic (3.555) > t table (1.988) it can be concluded as influence between service quality on customer satisfaction partially. Furthermore, the significance value of the price variable (X2) of $0.02<0.05$, and $t$ arithmetic (3.182) $>t$ table (1.988) can be concluded as a partial influence of price variables on customer satisfaction.

Whereas the $\mathrm{F}$ Test is a regression test of coefficients simultaneously. This test aims to determine the effect of all independent variables (X1 and $\mathrm{X} 2$ ) contained in the simultaneous model to the dependent variable $(Y)$, while for the $F$ test to test the significance of Quality Service and Price impacts on Consumer Satisfaction.

Tabel 2. Hypothesis F Testing ANOVA $^{\mathrm{a}}$

\begin{tabular}{|ll|r|r|r|r|r|}
\hline model & \multicolumn{1}{c|}{$\begin{array}{c}\text { sum of } \\
\text { squares }\end{array}$} & Df & \multicolumn{1}{c|}{$\begin{array}{c}\text { mean } \\
\text { square }\end{array}$} & $F$ & Significancy \\
\hline 1 & Regression & 103.312 & 2 & 51.656 & 20.802 & $.000^{\mathrm{b}}$ \\
& Residual & 240.878 & 97 & 2.483 & & \\
& Total & 344.190 & 99 & & & \\
\hline
\end{tabular}

a. Dependent of Variable: $Y$ satisfaction

a. Predictors: (Constant), X2 price, X1 service

Source : Processed Primary Data

Based on the above data, the significance value of the regression model in this study amounted to $0,000<0.05$ and $f$ arithmetic $(20,802)>$ f table (3.09), so the author can conclude there is an influence of variables $\mathrm{X} 1$ and $\mathrm{X} 2$ on the variable $\mathrm{Y}$ simultaneously.

\section{E. CONCLUSION}

Based on the research result, it can be concluded as follow: That Go-Jek Customer Satisfaction level in the Pamulang sub-district region is relatively good based on the questionaire answered by respondents. The average value of the service quality variable in the scale of intervals of 4.195 which is in the range of interval values of $3.41-4.20$ or in the good category. The average value of the variable price of 4.045 is also in the good category. Whereas the magnitude of the average consumer satisfaction value of 4.225 actually falls into a good category.

Based on the results of hypothesis test (t-test) on the variable $(\mathrm{X} 1)$ the quality of service $t$ value $(3,555)>t$ table $(1,988)$ can be concluded that the quality of service partially has a positive influence on customer satisfaction. Based on the results of partial hypothesis testing (t-test), the price variable obtained t value (3.182) > t table (1.988). Based on these data, it can be concluded that price partially has a positive effect on customer satisfaction. Based on the simultaneous test results (F-Test), the significance value of $0,000<0.05$ and $f$ arithmetic $(20,802)>f$ table (3.09).

In the multiple correlation test the significance value of $0,000<$ from 0.05 and the magnitude of the correlation coefficient $(R)$ of 0.548 , it can be concluded that there is a correlation between the variable $X$ to the variable $Y$, the correlation coefficient value of 0.548 which means the degree of 
correlation in this regression model included in the Medium category. While in the determination test, the coefficient is 0.300 . After all, it can be concluded that service quality and price simultaneously or jointly have a positive influence on customer satisfaction and a coefficient of determination of 0.300 or $30 \%$ shows the independent variables (service quality and price) are able to explain the dependent variable (customer satisfaction) of $30 \%$ While the remaining $70 \%$ are other variables outside this study.

\section{DAFTAR PUSTAKA}

Sumber Buku :

Alma Buchari (2014) Manajemen Pemasaran dan Pemasaran Jasa Alfabeta Bandung

Arikunto Suharsimi (2006) Prosedur Penelitian Suatu Pendekatan Praktik Rineka Cipta Jakarta

Bob sabran (2012) Marketing Management Erlangga Jakarta

Bungin Burhan (2013) Metode Penelitian Sosial dan Ekonomi : Format-format Kuantitatif dan Kualitatif untuk Studi Sosiologi, Kebijakan Publik, Komunikasi, Manajemen dan Pemasaran edisi Pertama Kencana Prenada Media Group Jakarta

Daryanto dan Ismanto setyobudi (2014) Konsumen dan Pelayanan Prima Gava Media Malang

Ferdinand Augustusy (2006) Metode Penelitian Manajemen Pedoman Penelitian untuk Skripsi, Tesis, dan Disertasi Ilmu Manajemen Badan Penerbit Universitas Diponegoro Semarang

Ghozali Imam (2013) Aplikasi Analisis Multivariate dengan Program IBM SPSS Badan Penerbit Universitas Diponegoro Semarang

Grifin Ricky W dan Ronald J Elbert (2009) Business, 8th Edition Pearson International Edition. New Jersey Prentice Hall

Hasibuan Malayu (2008) Manajemen : Dasar Pengertian dan Masalah PT. Bumi Aksara Jakarta

Istijanto (2009) Aplikasi Praktis Riset Pemasaran Gramedia Pustaka Utama. Jakarta

Kotler Philip and Kevin Lane Keller (2011) Manajemen Pemasaran Edisi 13 Erlangga Jakarta Lupiyoadi Rambat (2014) Manajemen Pemasaran jasa Edisi 3 Salemba empat. Jakarta

Sangadji E.M. dan Sopiah (2013) Prilaku konsumen dan pendekatan praktis disertai himpunan jurnal penelitian. Penerbit Andi Yogyakarta

Santoso, Singgih, Panduan Lengkap SPSS Versi 20, PT Media Elex Komputindo, Jakarta.2012

Sugiyono (2009) Metode penelitian kuantitatif kualitatif dan R\&D Alfabeta. Bandung 
Sugiyono, Metode Penelitian Pendidikan Pendekatan Kualitatif, Kuantitatif, dan R\&D Alfabeta. Bandung. 2014

Tjiptono Fandy dan Gregorius Chandra (2012) Pemasaran Stategik, Andi. Yogyakarta

Tjiptono, Fandy dan Gregorius Chandra (2011) service quality and satisfaction Andi. Yogyakarta

Jurnal :

Aisyah Azzahra (2017) Pengaruh Kualitas Produk terhadap Keputusan Pembelian Jamu Tolak Angin Sido Muncul (Studi kasus pada konsumen pengguna jamu di perumahan bukit dago). Skripsi. Fakulutas Ekonomi. Universitas Pamulang. Tangerang Selatan

Fajar Syahputra (2016) Pengaruh Kepemimpinan dan Motivasi Kerja terhadap Kinerja Karyawan pada PT Djasa Ubersakti Jakarta Skripsi. Fakultas Ekonomi. Universitas Pamulang. Tangerang Selatan

Widi Kristiawan (2015) Analisis Pengaruh Kualitas Pelayanan, Kualitas Produk, Harga, dan Lokasi terhadap Kepuasan Pelanggan (Kitchenerwok and grill). Tesis. Magister Manajemen. Universitas Pamulang : Tangerang Selatan.

Website :

https://www.go-jek.com(diakses 12 Oktober 2018)

http://digilib.mercubuana.ac.id/manager/n!@file_skripsi/lsi4395163773687.pdf (diakses 14 Oktober 2018)

http://afrizalrkwaruwu.blogspot.co.id/2014/06/Makalah-Kebijakan-Harga.html?m=1 (diakses 27 Juli 2018)

www.Definisi-pengertian.com/2015/07/Definisi-Pengertian-Pelayanan.html?m=1(diakses 14 Juli 2018)

Etalasepustaka.blogspot.co.id/2016/08/Pengertian-Indikator-Kepuasan-Pelanggan-MenurutPara-Ahli.html?m=1 (diakses 12 Juli 2018)

Gojekid.blogspot.com/2016/09/Profil-Perusahaan-Gojek.html?m=1(diakses 12 Okto-ber 2018)

https://administrasibisnis.studenjournal.ub.ac.id/ Jurnal Administrasi Bisnis vol.61 no.2, 2018. (diakses 14 Maret 2019)

http://jurnaljam.ub.ac.id/ Jurnal Aplikasi Manajemen Vol.11 No3, 2013.(diakses 14 Maret 2019)

https://ejournal.unsrat.ac.id/ Jurnal EMBA Vol.3 No.2, 2015. (diakses 14 Maret 2019) 
https://ejournal.unsrat.ac.id/ Jurnal EMBA Vol.6 No.3, 2018. (diakses 14 Maret 2019)

https://ejournal.undiksha.ac.id/ International Journal of Social Science and Business, Vol.2 No.3,2018 (diakses 14 Maret 2019) 